\title{
Effect of VAT Adoption on Manufacturing Firms in Ethiopia
}

\author{
Soule Sow $^{1} \&$ Mesay Gebresilasse ${ }^{2}$ \\ ${ }^{1}$ Columbia University, Islamic Development Bank, Jeddah, Saudi Arabia \\ ${ }^{2}$ Amherst College, Massachusetts, US \\ Correspondence: Soule Sow, Senior Global Value Chain Specialist, Islamic Development Bank, Saudi Arabia. \\ Tel: 966-558-204-319. E-mail: ss3721@ columbia.edu.
}

Received: August 10, 2020

Accepted: September 8, 2020

Online Published: September 18, 2020

doi:10.5539/ijef.v12n10p75

URL: https://doi.org/10.5539/ijef.v12n10p75

\begin{abstract}
To remedy their low fiscal capacity problem, many developing countries adopted value-added taxation because they believe it will raise tax revenue and improve the production efficiency of firms. In this paper, we study the impact of the adoption of the value-added tax (VAT) on firms by analyzing the introduction of VAT in Ethiopia in 2003 using panel data of manufacturing firms (1996-2009). By law, a firm is required to register for VAT if it is big (its revenue is higher than 500,000 Birr); otherwise, the firm is small and faces a much lower turnover tax rate. Using a difference in differences strategy with big firms as a treatment and small firms as control, and excluding firms that might potentially bunch around the threshold, we find taxes paid, reported revenue, taxes paid out of revenue, value-added, and raw materials use increase for big firms. However, the share of inputs in revenue fell suggesting VAT increased revenue efficiency by not production efficiency.
\end{abstract}

Keywords: value-added taxation, production efficiency, revenue efficiency

\section{Introduction}

Fiscal capacity, the ability to generate revenue through taxation, is still very low in developing countries (Besley and Persson (2013)). The belief is fiscal constraints hinder the economic development of these countries because of a lack of resources to invest infrastructure, education, and other growth-enhancing projects. The ability of governments to tax enterprises is particularly low because the informal sector is big in these countries. In addition, for governments to be able to tax, they need to have information on transactions; information that is acutely lacking because of high evasion. To deal with this information challenge, economists highlight the importance of third party information, the ability of the tax authority to verify the reports of the taxpayers against other sources, such as the reports of a firm's trading partners (Kopczuk \&Slemrod, 2006; Gordon \& Li, 2009; Kleven et al., 2009). Moreover, Even in a second best environment, tax systems should aim to achieve production efficiency (Diamond \& Mirrlees, 1971). Thus, for the past few years, following the advice of economists and international organizations, over 140 countries have adopted value-added taxation.

In this paper, we study the impact of VAT on firms' revenue efficiency (taxes paid) and production efficiency (value-added and the use of inputs) by exploiting the adoption of VAT in Ethiopia in 2003 and using manufacturing firm-level panel data (1996-2009). By law, a firm is required to register for VAT if it is big (its revenue is higher than 500,000 Birr); otherwise, the firm is small and faces a much lower turnover tax rate. Using a difference in differences strategy with big firms as a treatment and small firms as control, and excluding firms that might potentially bunch around the threshold, we find taxes paid, reported revenue, taxes paid out of revenue, value-added, and raw materials use increase for big firms. However, the share of inputs in revenue falls suggesting VAT increase revenue efficiency by not production efficiency.

We use firm-level data and a policy change in Ethiopia to analyze the administrative, economic, and market impacts of VAT on firms. We use panel data (1996-2009) from the Large and Medium Manufacturing Industries Survey conducted annually by the Central Statistical Agency of Ethiopia. Manufacturing is defined, according to International Standard Industrial Classification as the physical or chemical transformation of materials or components into new products, whether the work is driven by power-driven machines or by hand, whether it is done in a factory or the worker's home, or whether the products are sold at wholesale or retail. Due to administrative feasibility considerations, the Ethiopian government set a threshold above which firms are required to register for VAT and below which firms pay a low flat tax (called a turnover tax). To estimate the 
effects of VAT, we use a difference in differences strategy using big firms as treatment and small firms as controls. However, there is concern that firms around the VAT registration threshold may manipulate the reported revenue to evade the VAT and move to the lower turnover tax regime. The analysis of the bunching around the threshold, which was conducted in Gebresilasse and Sow (2015), informs us about the range around the threshold to exclude for the difference-in-differences estimation.

As shown in that paper, bunching firms reduce their reported revenue by 48,000 Birr in response to the VAT registration threshold. Therefore, firms with revenue slightly above the threshold lower their revenue by about $10 \%$ to become VAT eligible. Thus if we include all firms in our analysis of the impact of VAT on outcomes of VAT firms, some of the results will be masked by the misspecification of size by some firms. The bunching estimate obtained from Gebresilasse and Sow (2015) allows us to create an exclusion range which consists of firms we believe might be manipulating their VAT eligibility. Using this range, we can define VAT firms (big firms) and non-VAT firms (small firms) relative to the VAT threshold excluding this range.

We find three sets of results from our difference in differences estimation, and these results show the administrative, economic, and market effects of VAT on big firms. The first administrative effect is that relative to small firms, big firms pay more taxes, and pay a higher ratio of taxes paid to revenue made. The second administrative effect is increased "formality", as defined by whether a firm keeps books of accounts or not: small firms relative to big firms increase "formality". The first economic effects are: relative to small firms, big firms increase reported revenue, value-added, use of foreign raw material inputs, and wage bill paid; but the ratio of total inputs to revenue falls. Finally, the market effect is that exporters, even though they benefit from a favorable zero-rated VAT tax, do not experience increases in reported revenue, value-added, or use of raw materials relative to non-exporters. First, these results suggest revenue efficiency from VAT increases: VAT improves the intensive margin of compliance from big firms by bringing more of their revenue under the VAT "net", which likely due to the paper trail effect. Therefore, it is also likely that small firms find it worthwhile to prove they are VAT ineligible, and so they become "formal" by keeping books of accounts. Second, production appears to have improved considerably as both taxes paid and share of taxes paid in revenue increases. Third, the results suggest that, because relative to small firms big firms lowered their share of raw material inputs and the share of total inputs, production efficiency appears not to have improved. Big firms just increase their use of raw materials to match their increase in reported revenue. They did not use their saving on input taxes to buy more inputs or hire more workers or pay a higher share of wages in revenue (the estimate of this variable is negative).

This paper contributes to the relatively new literature on value-added taxation: the effectiveness of third party information, and productive efficiency on consumption tax. VAT, which is a tax on value-added only, in theory, facilitates enforcement via a structure that incentivizes third party reporting and hence generates a transaction paper trail between firms. Therefore, firms cannot easily hide a transaction involving a third party from the government (Tait, 1972); Burgess and Stern (1993); Agha and Haughton (1996); Kopczuk and Slemrod (2006)). Pomeranz (2013) analyzes the role of third party information for VAT enforcement through randomized experiments and demonstrate that announcing additional monitoring has less impact on transactions that are subject to a paper trail, indicating VAT's paper trail effect has a preventive deterrence effect.

We find in this paper that relative to small firms big firms increase raw material used by the same percentage than their increase in reported revenue. These results are consistent with the findings in Carrillo et al. (2014). They find that when firms are notified by the tax authority about detected revenue discrepancies on previously filed corporate income tax returns, firms increase reported revenue but also increase reported costs, by 96 cents for every dollar of revenue adjustment.

VAT is also supposed to eliminate the cascading effect of output tax, and thus make production more efficient. Therefore, even in a second-best environment, tax systems should aim to achieve production efficiency (Diamond \& Mirrlees, 1971). This result implies governments should impose a tax on consumption, wages and profits, but not on intermediate inputs, turnover, and trade: this is one of the main reasons why VAT is so attractive to policymakers. However, the benefits of production efficiency are limited in an environment with high administrative costs and high evasion or informality. In effect, in an environment where evasion and informality are pervasive, we can achieve greater revenue efficiency by lowering evasion even if production efficiency suffers (Best et al., 2014). Because of this trade-off and other administrative feasibility considerations, when implementing VAT, governments set a threshold above which firms are required to register for VAT and below which firms pay a low flat tax (often called a turnover tax).

This paper is organized as follows. Section 2 gives a brief description of the VAT policy in Ethiopia; section 3 presents the empirical strategy of the bunching and difference in differences estimations; section 4 describes the 
firm-level data and the main variables used; Section 5 presents and discusses the results; section 6 concludes.

\section{Value Added Tax: The Policy}

The government of Ethiopia introduced value-added taxation on January 1, 2003, to replace sales taxes. To follow the global trend toward indirect taxation, and improved fiscal capacity, Ethiopia introduced VAT with a 15\% rate. VAT taxes are due at the end of each month. Input taxes on raw materials (except alcohol) are refundable. Exemptions exist for certain good supplies or services. Exports, the supply of gold to the National Bank, and other specific transactions (very few) are zero-rated.

This rate applies to all firms with a turnover of more than 500000 Birr. For firms with less than the turnover threshold of 500000 Birr, a much lower $2 \%$ flat rate is applied. The law requires any firm with high enough turnover to register for VAT. The turnover tax applies to local services. It aims to raise, in equivalent terms, revenue from non-registered firms. The government is implicitly assuming VAT feasibility and applicability hinges on the fact that the VAT registration requirement depends on firm size. Reasons to define a threshold include the costs of compliance with VAT due to the small scale and the optimal balance between a low flat turnover tax and a VAT tax.

The purpose of the VAT is to only tax value-added, eliminate the cascading effect of sales taxes, and hence improve production efficiency. Thus, at the practical level, the value-added tax that a registered business pays to the government is the difference between the tax paid on inputs and taxes collected from output. Therefore, VAT eliminates the distortionary effect of sales on production since firms are no longer taxed twice. Moreover, the VAT introduces a paper trail effect because at the intermediate level proper reporting increases substantially. Thus, governments are expected to increase tax revenue from VAT.

\section{Empirical Strategy}

We present a difference in differences in the empirical specification to estimate the impact of VAT policy on big firms (our treatment) relative to small firms (our control). To do so we use our bunching estimates obtained from Gebresilasse and Sow (2015); it allows us to create an exclusion range which consists of firms we believe might be manipulating their VAT eligibility (change revenue to revenue below the threshold to be VAT ineligible). Using this range, we can define VAT firms (big firms) and non-VAT firms (small firms).

To estimate the impact of VAT policy on big firms (our treatment group) relative to small firms (or control groups), we exploit the policy change on January 1st, 2003. Identification in a difference in difference analysis relies on parallel trends for treatment and control groups. Here is the specification:

$$
Y_{i t}=\alpha+\beta_{1} \text { Treatment }_{i}+\beta_{2} \text { Post }_{t}+\beta_{3} \text { Treament }_{i} \times \text { Post }_{t}+\mu_{i}+v_{r}+\rho t+\gamma X_{i t}+s_{i t}
$$

Where Treatment $t_{i}$ is a dummy whether a firm's revenue greater than the 500000 threshold (or VAT eligible). Post $_{t}$ is a dummy for whether year is greater than 2002; and $X_{i t}$ is a vector of controls such as firm age, firm ownership type, and lag of log sale to control for firm size trends; $\mu_{i}$ is firm fixed effect, $v_{r}$ is region fixed effect, and $\rho t$ is time trend.

Because of the potential bunching of some firms around the threshold, we define VAT eligibility by excluding all firms with revenue within 58,000 of the threshold, a range obtained from the bunching estimates in Gebresilasse and Sow (2015). The interval can vary for different specifications. The identification assumption of parallel trends across treatment and control groups, before the policy change, appears to hold (Figure 1).

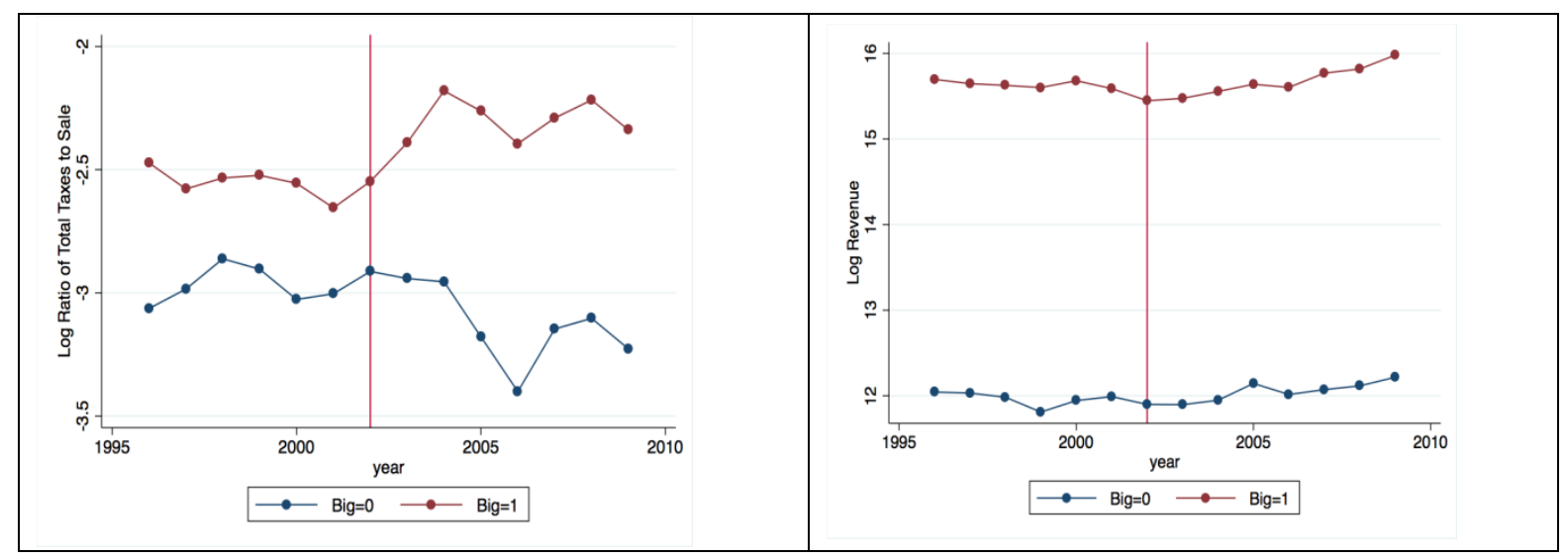




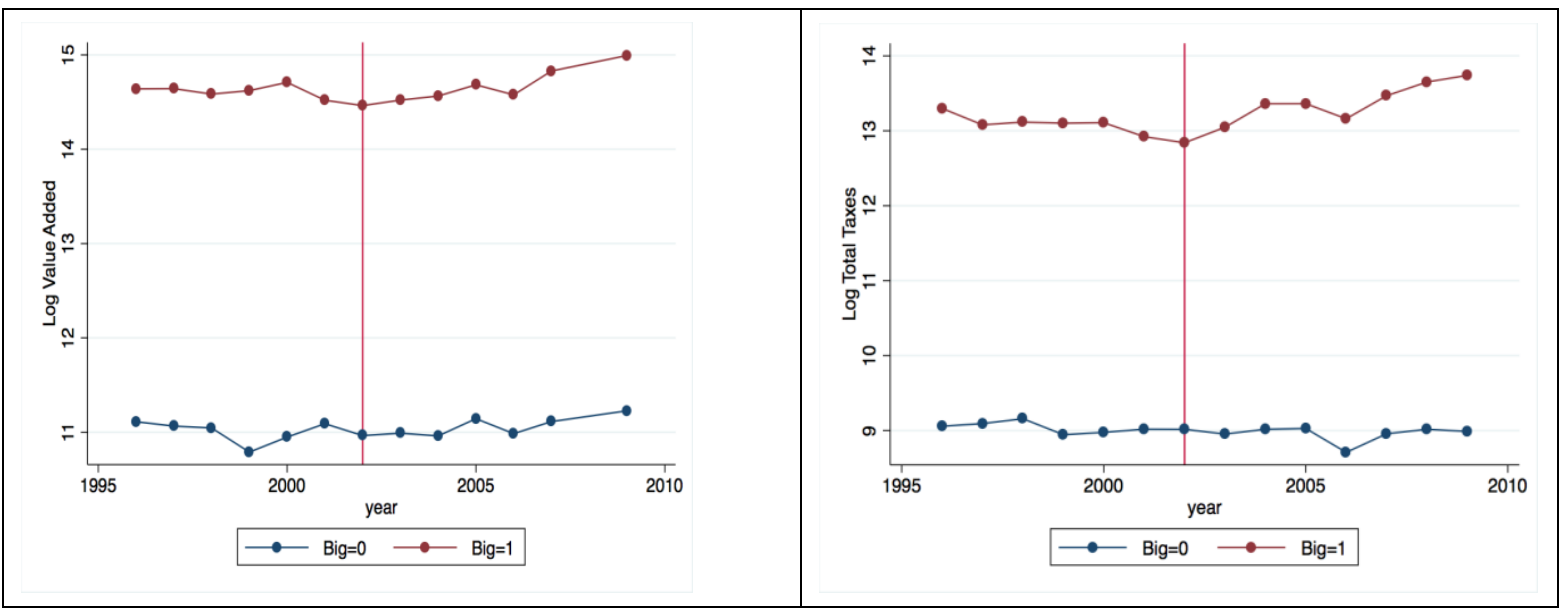

Figure 1. Parallel trends before and after introduction of VAT policy: taxes, valued-add, revenue and profits Note. Big indicates a firm with revenue higher than 500000 Birr. The graph is plotted using the program binscatter, developed by Michael Stepner (https://michaelstepner.com/binscatter/) See Chetty, Friedman and Rockoff (2014) as source example. It plots non-parametrically the average $\mathrm{y}$ value for each $\mathrm{x}$ value grouping them into equal size bins, measures the mean of each variable, and finally generates a scatter plot.

\section{Data}

Our analysis is based on firm-level panel data from Ethiopia covering all regions of the country from 1996 to 2009. More precisely, the data is from the Large and Medium Manufacturing Industries Survey (LMMIS), conducted annually by the Central Statistical Agency of Ethiopia. Manufacturing is defined, according to International Standard Industrial Classification as "the physical/chemical transformation of materials/parts by power-driven machines/hands in a factory/home into products sold at wholesale or retail. Manufacturing also includes the assembly of components. The LMMIS data comprises of: (1) firms that with 10 or more employees; (2) firms that use a power-driven manufacturing process; (3) private and public firms. From the survey, we have an unbalanced panel data of manufacturing firms (at the 4-digit level).

An example of the industry with digit code 1920 is a Manufacturer of footwear. About $70 \%$ of firms are located in the 3 biggest regions of Ethiopia (the biggest being Adis Abeba). In our analysis, we do control for region fixed effects. The data covers 44 industries with an average of 1000 firms per year with 623 in 1996 and 1,948 in 2009. The level of observation is at the firm level. For the difference in differences regressions, only firms present before and after the adoption of VAT policy are used.

The main variables used in our regressions are described in the summary statistics Table 1.

Table 1. Summary statistics

\begin{tabular}{lccc}
\hline Variable & Mean & Std. Dev. & N \\
\hline Total sales value & 101.641 & 350.329 & 4425 \\
Indirect Taxes & 17.428 & 87.593 & 3880 \\
Income tax paid on profit & 7.437 & 35.417 & 2337 \\
Total taxes paid & 20.527 & 104.65 & 4133 \\
Total wage bill & 7.107 & 19.495 & 4373 \\
Total value of local raw materials & 26.841 & 76.572 & 4058 \\
Total value of Imported raw materials & 32.392 & 155.359 & 3178 \\
Total value of other inputs & 7.55 & 51.692 & 4332 \\
Total working capital & 61.449 & 211.346 & 3794 \\
Investment on Fixed Capital & 12.427 & 42.338 & 2076 \\
Total number of employees & 119.082 & 324.443 & 4361 \\
Age of firm & 24.97 & 14.989 & 3171 \\
Type of ownership & 1.208 & 0.419 & 4452 \\
Keep book of accounts & 0.636 & 0.481 & 4452 \\
\hline
\end{tabular}

Note. Monetary values in millions (Ethiopian Birr). Type of ownership is a dummy which takes a value of 1 if the firm is private, and 0 if public. Keep book of accounts is a dummy which takes a value of 1 if the firm keeps book, and zero if not. 
Revenue is the total sales value. Indirect taxes are equal to sales tax for all firms before the VAT policy; after the policy, indirect taxes are equal to value-added tax for VAT-registered firms and turnover tax for non-registered VAT firms. Profit taxes are income taxes paid on firm profit. Thus, total taxes are equal to the sum of all taxes paid. The wage bill is the total wages paid to all employees, which is represented by the variable workers. Local raw materials and foreign raw materials used are non-processed material inputs from Ethiopia and abroad, respectively. Other inputs are any input other than raw materials, workers, or capital. Working capital is current asset minus liabilities, whereas investment represents total investment on fixed capital. As part of controls in the difference in differences regression, We use the age of firm and type of ownership. We compute Age of the firm from the variable "year firm was started". Type of ownership is a dummy indicating whether a firm is publicly or privately owned. Finally, keepbook is a dummy indicating whether a firm keeps books of accounts or not.

\section{Results}

We present our difference in differences estimates: how firm outcomes change for VAT (big) firms relative to non-VAT(small) firms. These outcomes are grouped into administrative outcomes ("formality" and taxes paid), economic outcomes (revenue, value-added, inputs), and market outcomes (exports). In all tables, robust standard errors, in parenthesis, are clustered at the industry level. Big means firm with revenue higher than the VAT eligibility threshold of 500,000 Birr. Control variables include age of firms, type of ownership (private or public). The excluded threshold range includes all firms that are at least 58,000 Birr away (below and above) from the turnover threshold. In all regression, we include firm fixed effect, region fixed effect, and year time trend.

The first finding is that, after the policy, small firms are more likely to keep books of accounts relative to big firms (Table 2 ) even though big firms seem to increase their book keeping as well.

Table 2. Effect of VAT policy on whether firm keeps books of accounts

\begin{tabular}{llllll}
\hline & $(1)$ & $(2)$ & $(3)$ & $(4)$ & $(5)$ \\
\hline Post2002×Big & $-0.055^{* *}$ & $-0.213^{* * *}$ & $-0.213^{* * *}$ & $-0.254^{* * *}$ & $-0.280^{* * *}$ \\
& $(0.021)$ & $(0.025)$ & $(0.025)$ & $(0.041)$ & $(0.042)$ \\
AgeFirm & & & 0.008 & 0.005 \\
& & & $(0.014)$ & $(0.015)$ \\
Type of ownership & & & $0.053^{* * *}$ & $0.049^{* * *}$ \\
& & & $(0.017)$ & $(0.017)$ \\
Lag Log Sale & & & $0.015^{* * *}$ & $0.013^{* *}$ \\
& & & $(0.005)$ & $(0.006)$ \\
\hline Observations & 7429 & 7429 & 4594 & 4408 \\
R2 & 0.112 & 0.152 & 7429 & 0.162 & 0.162 \\
Firm FE and Year Trend & Yes & Yes & 0.156 & Yes & Yes \\
Year FE & No & Yes & Yes & Yes & Yes \\
Region FE & No & No & Yes & Yes & Yes \\
Controls & No & No & Yes & Yo & Yes \\
Excluding Threshold Range & No & No & No & No & Yes \\
\hline
\end{tabular}

Note. Dependent variable is a dummy variable indicating whether the firm keeps books of account or not. Significance levels: $* * *(1 \%)$, $* *(5 \%)$, and $*(10 \%)$. Big means firm with revenue higher than the VAT eligibility threshold of 500000 Birr. Control variables include age of firms, type of ownership (private or public). The excluded threshold range includes all firms that are at least 58,000 Birr away (below and above) from the turnover threshold.

Formality is hard to measure but it is highly plausible that a firm that starts keeping books of accounts is providing more information to the government: so the firm is more formal (at least at the intensive margin). The structure of the VAT policy in Ethiopia can explain why small firms increase formalization relative to big firms after the adoption of the policy. Small firms are not required to register for VAT, and face low turnover tax (sale tax); and so to take advantage of this differential tax treatment they start keeping books to qualify for turnover tax.

Both taxes paid and the ratio of taxes paid to revenue increase for big firms relative to small firms. Indirect and total taxes paid by big firms increase by $73 \%$ and $61 \%$, respectively, relative to small firms (Table 3). The same is true for-profit taxes but the coefficient is not significant. The ratio of indirect taxes to revenue and ratio of total taxes to revenue by big firms increase by $54 \%$ and $45 \%$ relative to small firms. 
Table 3. Effect of VAT policy on taxes paid

\begin{tabular}{lccc}
\hline & $(1)$ & $(2)$ & $(3)$ \\
& Log Indirect Taxes & Log Profit Taxes & Log Total Taxes \\
\hline Post2002×Big & $0.732 * * *$ & 0.046 & $0.610 * * *$ \\
& $(0.149)$ & $(0.191)$ & $(0.097)$ \\
AgeFirm & -0.030 & 0.036 & $(0.079)$ \\
& $(0.083)$ & $(0.135)$ & 0.044 \\
Type of ownership & 0.046 & $0.509 * *$ & $(0.083)$ \\
& $(0.086)$ & $(0.191)$ & $0.397 * * *$ \\
Lag Log Sale & $0.390 * * *$ & $0.442 * * * 040)$ \\
(0.045) & 3809 & $(0.065)$ & 4112 \\
Observations & 0.341 & 2494 & 0.327 \\
R2 & Yes & 0.224 & Yes \\
Firm FE and Year Trend & Yes & Yes & Yes \\
Year FE & Yes & Yes & Yes \\
Region FE & Yes & Yes & Yes \\
Controls & & Yes & Yes \\
Excluding Threshold Range & Yes & \\
Note. Dependent variables are log of indirect taxes, profit taxes, and total taxes. Significance levels: ***(1\%), **(5\%), and *(10\%). Robust \\
standard errors (in parenthesis). Clustering at the industry level. Big means firm with revenue higher than the VAT eligibility threshold of \\
500000 Birr. Control variables include age of firms, type of ownership (private or public). The excluded threshold range includes all firms \\
that are at least 58,000 Birr away (below and above) from the turnover threshold.
\end{tabular}

However, the ratio of profit taxes to revenue falls by $30 \%$ relative to small firms. The increase in taxes paid suggests the effectiveness of VAT in raising revenue from VAT eligible firms because of its ability to facilitate enforcement via a structure that incentivizes third party reporting and hence generates a transaction paper trail between firms. More specifically, VAT should raise firms reported revenue.

Reported revenue for big firms increases by $21 \%$ relative to small firms while value-added increases by $21 \%$ (Table 4).

Table 4. Effect of VAT policy on production efficiency: output

\begin{tabular}{lcc}
\hline & Log Revenue & Log Value Added \\
\hline Post $_{2002}$ x Big & $0.212^{* * *}$ & $0.207^{* * *}$ \\
AgeFirm & $(0.048)$ & $(0.073)$ \\
& -0.026 & -0.026 \\
Type of ownership & $(0.056)$ & $(0.065)$ \\
& 0.039 & 0.063 \\
Lag Log Sale & $(0.064)$ & $(0.085)$ \\
& $0.367^{* * *}$ & $0.348^{* * *}$ \\
Observations & $(0.039)$ & $(0.045)$ \\
$R^{2}$ & 4390 & 3606 \\
Firm FE and Year Trend & 0.542 & 0.392 \\
Year FE & Yes & Yes \\
Region FE & Yes & Yes \\
Controls & Yes & Yes \\
Excluding Threshold Range & Yes & Yes \\
\hline
\end{tabular}

Note. Dependent variables are revenue, value-added, local raw materials, and foreign raw materials (in logs). Significance levels: $* * *(1 \%)$, $* *(5 \%)$, and $*(10 \%)$. Robust standard errors (in parenthesis). Clustering at the industry level. Big means firm with revenue higher than the VAT eligibility threshold of 500000 Birr. Control variables include age of firms, type of ownership (private or public). The excluded threshold range includes all firms that are at least 58,000 Birr away (below and above) from the turnover threshold.

Revenue may increase due to both reporting and economic effects. The reporting effect may be due to the increase in information on firm transactions created by the VAT whereas the economic effect may be due to firms 
increasing their production efficiency as only value added is taxed. Value-added, which is the difference between a firm's sale and its purchases of inputs from other firms, has increased for big firms relative to small firms, which seems to suggest evidence of increased production efficiency. But we need to analyze further the use of inputs to determine whether the increase in value-added is at least partly due to the production efficiency benefits of VAT.

Big firms increase the use of raw materials relative to small firms. In particular, the use of foreign raw materials increases by $38 \%$ (see Table 5), and total raw materials use increase by $21 \%$ (the coefficient of outcome local raw materials use is positive but insignificant). But these results (big firms relative to small firms) also suggest the use of other inputs fell while the use of overall inputs increased even though both results are statistically insignificant. The main finding here is the increase in total raw material use matches that of value-added (21\%), whereas the ratio of total inputs to revenue falls by $21 \%$.

Table 5. Effect of VAT policy on production efficiency: input

\begin{tabular}{lccc}
\hline & Local Raw Material & Foreign Raw Material & Total Raw Material \\
\hline Post $_{2002} \times$ Big & 0.110 & $0.378^{* *}$ & $0.204^{* *}$ \\
AgeFirm & $(0.115)$ & $(0.168)$ & $(0.078)$ \\
& 0.039 & $-0.286^{* *}$ & -0.079 \\
Type of ownership & $(0.066)$ & $(0.126)$ & $(0.073)$ \\
& 0.069 & 0.166 & 0.065 \\
Lag Log Sale & $(0.115)$ & $(0.142)$ & $(0.068)$ \\
& $0.344^{* * *}$ & $0.469^{* * *}$ & $0.388^{* * *}$ \\
\hline Observations & $(0.044)$ & $(0.070)$ & $(0.043)$ \\
$R^{2}$ & 3862 & 3207 & 4390 \\
Firm FE and Year Trend & 0.228 & 0.218 & 0.411 \\
Year FE & Yes & Yes & Yes \\
Region FE & Yes & Yes & Yes \\
Controls & Yes & Yes & Yes \\
Excluding Threshold Range & Yes & Yes & Yes \\
\hline
\end{tabular}

Note. Dependent variables are local raw materials, foreign raw material, and total raw materials (in logs). Significance levels: $* * *(1 \%)$, $* *(5 \%)$, and $*(10 \%)$. Robust standard errors (in parenthesis). Clustering at the industry level. Big means firm with revenue higher than the VAT eligibility threshold of 500000 Birr. Control variables include age of firms, type of ownership (private or public). The excluded threshold range includes all firms that are at least 58,000 Birr away (below and above) from the turnover threshold.

Wage bill and working capital of big firms increase relative to small firms suggesting big firms are responding to VAT by readjusting their production process. In effect, the wage bill and working capital increase by $14 \%$ and $22 \%$ respectively (see Table A3). The results suggest VAT increases the working capital of firms as lower taxes are paid on production, and thus firms pay workers more: maybe because they want to increase product quality. However, these results on wages and working capital do not seem to be robust, as the difference in differences figures (Figure A1) do not show visible differential changes when VAT is introduced. One of the goals of VAT is to stimulate exports: the VAT is zero-rated for exporters. In a country such as Ethiopia, where the exchange rate is managed, the impact of VAT on exporters should be visible. Exporters do not experience increases in report revenue, value-added or use of raw materials relative to non-exporters; where exporters are treatment and other firms (big or small) are control. This result was not expected (Table A4).

First, these results suggest revenue efficiency from VAT policy: VAT improves the intensive margin of compliance from big firms by bringing more their revenue under the VAT "net", which is likely due to the paper trail effect. Therefore, it is also likely that small firms find it worthwhile to prove they are VAT ineligible, and so they become "formal" by keeping books of accounts. Second, the results suggest that because relative to small firms big firms lowered their share of raw material inputs in revenue and the share of total inputs in revenue, production efficiency appears not to have improved. Big firms just increase their use of raw materials to match their increase in reported revenue. They did not use their saving on input taxes to buy more inputs or hire more workers or pay a higher share of wages in revenue.

\section{Conclusion}

The wide adoption of VAT in developing countries in recent years has been facilitated by the long-held belief 
that VAT creates enforcement via a structure that incentivizes third party reporting and hence generates a transaction paper trail between firms and therefore generates more tax revenue. Furthermore, by eliminating the cascading effect of output taxes, it should improve production efficiency; which is economically desirable. In this paper, we study the impact of VAT on firms by exploiting the adoption of VAT in Ethiopia in 2003 and using panel data of manufacturing firms (1996-2009). By law, a firm is required to register for VAT if it is big (its revenue is higher than 500,000 Birr); otherwise, the firm is small and faces a much lower turnover tax rate. Using difference in differences with big firms as a treatment and small firms as control, we find: "formality" increase at the intensive margin; revenue efficiency increases, but production efficiency appear to have stagnated.

First, VAT improves the intensive margin of compliance from big firms by bringing more of their revenue under the VAT "net", which likely due to the paper trail effect. Therefore, it is also likely that small firms find it worthwhile to prove they are VAT ineligible, and so they become "formal" by keeping books of accounts. Second, production appears to have improved considerably as both taxes paid and share of taxes paid in revenue increases. Finally, because relative to small firms big firms lowered their share of raw material inputs and the share of total inputs, production efficiency appears not to have improved. Big firms just increase their use of raw materials to match their increase in reported revenue. They did not use their saving on input taxes to buy more inputs or hire more workers or pay a higher share of wages in revenue.

\section{Acknowledgments}

This paper emanates from the third chapter of my Ph.D. Dissertation at Columbia University where I graduated in 2015. I am deeply indebted to my dissertation advisor Suresh Naidu, who was a tremendous source of insight and advice. I would like to thank my committee members, David Weinstein, Jonas Hjort, Dan O'Flaherty, and Donald Davis for invaluable discussions, guidance, and support.

\section{References}

Agha, A., \& Haughton, J. (1996). Designing Vat Systems: Some Efficiency Considerations. The Review of Economics and Statistics, 78(2), 303-308. https://doi.org/10.2307/2109932

Besley, T.,\& Persson, T. (2013). Chapter 2 - Taxation and Development. In A. J. Auerbach, R. Chetty, M. Feldstein, \& E. Saez (Eds.), Handbook of Public Economics (Vol. 5, pp. 51-110). https://doi.org/10.1016/B978-0-444-53759-1.00002-9.

Best, M. C., Brockmeyer, A., Kleven, H. J., Spinnewijn, J., \& Waseem, M. (2015). Production versus Revenue Efficiency with Limited Tax Capacity: Theory and Evidence from Pakistan. Journal of Political Economy, 123(6), 1311-1355. https://doi.org/10.1086/683849

Burgess, R., \& Stern, N. (1993). Journal of Economic Literature, 31(2), 762-830.

Carrillo, P., Dina, P., \& Monica, S. (2017). Dodging the Taxman: Firm Misreporting and Limits to Tax Enforcement. American Economic Journal: Applied Economics, 9(2), 144-64. https://doi.org/10.1257/app.20140495

Chetty, R., John, N. F., \& Jonah, E. R. (2014). Measuring the Impacts of Teachers II: Teacher Value-Added and Student Outcomes in Adulthood. American Economic Review, 104(9), 2633-79. https://doi.org/10.1257/aer.104.9.2633

Diamond, P. A., \& Mirrlees, J. A. (1971). Optimal Taxation and Public Production. American Economic Review, 61, 8-27.

Gordon, R., \& Li, W. (2009). Tax structures in developing countries: Many puzzles and a possible explanation. Journal of Public Economics, 93(7), 855-866. https://doi.org/10.1016/j.jpubeco.2009.04.001

Kleven, H. J., Kreiner, C. T., \& Saez, E. (2016). Why Can Modern Governments Tax So Much? An Agency Model of Firms as Fiscal Intermediaries. Economica, 83, 219-246. https://doi.org/10.1111/ecca.12182

Kopczuk, W., \& Joel, S. (2006). Putting Firms into Optimal Tax Theory. American Economic Review, 96(2), 130-134. https://doi.org/10.1257/000282806777212585

Mesay, G., \& Soule, S. (2015). Firm Response to VAT Registration Threshold in Ethiopia. Working Paper. Retrieved from https://academiccommons.columbia.edu/doi/10.7916/D8Z0377W

Pomeranz, D. (2015). No Taxation without Information: Deterrence and Self-Enforcement in the Value Added Tax. American Economic Review, 105(8), 2539-69. https://doi.org/10.1257/aer.20130393

Tait, A. A. (1972). Value Added Tax. London: McGraw-Hill. 


\section{Appendix}

This section provides further evidence of revenue efficiency vs production efficiency trhough additional tables and figures: see Table A1, Table A2, Table A3, and Table A4; see also Figure A1, Figure A2

Table A1. Effect of VAT policy on share of taxes paid out of revenue (Indirect (1), Profit (2), Total taxes (3))

\begin{tabular}{|c|c|c|c|}
\hline & Indirect Taxes & Profit Taxes & Total taxes \\
\hline \multirow[t]{2}{*}{ Post $_{2002} \times$ Big } & $0.538^{* * *}$ & $-0.302^{*}$ & $0.445^{* * *}$ \\
\hline & $(0.135)$ & $(0.159)$ & $(0.097)$ \\
\hline \multirow[t]{2}{*}{ AgeFirm } & 0.004 & 0.114 & -0.000 \\
\hline & $(0.073)$ & $(0.103)$ & $(0.062)$ \\
\hline \multirow[t]{2}{*}{ Type of ownership } & 0.009 & $0.479^{* * *}$ & 0.013 \\
\hline & $(0.084)$ & $(0.130)$ & $(0.063)$ \\
\hline \multirow[t]{2}{*}{ Lag Log Sale } & -0.003 & 0.104 & 0.024 \\
\hline & $(0.039)$ & $(0.064)$ & $(0.035)$ \\
\hline Observations & 3793 & 2486 & 4096 \\
\hline $\mathrm{R}^{2}$ & 0.050 & 0.043 & 0.035 \\
\hline Firm FE and Year Trend & Yes & Yes & Yes \\
\hline Year FE & Yes & Yes & Yes \\
\hline Region FE & Yes & Yes & Yes \\
\hline Controls & Yes & Yes & Yes \\
\hline Excluding Threshold Range & Yes & Yes & Yes \\
\hline
\end{tabular}

Note. levels: $* * *(1 \%), * *(5 \%)$, and $*(10 \%)$. Robust standard errors (in parenthesis). Clustering at the industry level. Big means firm with revenue higher than the VAT eligibility threshold of 500000 Birr. Control variables include age of firms, type of ownership (private or public). The excluded threshold range includes all firms that are at least 58,000 Birr away (below and above) from the turnover threshold.

Table A2. Effect of VAT policy on production efficiency: share of inputs

\begin{tabular}{lcccc}
\hline & Other & Total & Revenue Share of & \multicolumn{2}{c}{ Revenue Share of } \\
Inputs & -0.005 & 0.062 & -.0072 & $-.108^{* *}$ \\
\hline Post ${ }_{2002} \times$ Big & $(0.119)$ & $(0.072)$ & $(.055)$ & $(.049)$ \\
AgeFirm & 0.070 & 0.005 & -0.010 & -0.005 \\
& $(0.124)$ & $(0.082)$ & $(0.029)$ & $(0.106)$ \\
Type of ownership & $0.181^{*}$ & 0.052 & -0.075 & -0.034 \\
& $(0.099)$ & $(0.064)$ & $(0.091)$ & $(0.064)$ \\
Lag Log Sale & $0.308^{* * *}$ & $0.373^{* * *}$ & -0.013 & -0.053 \\
& $(0.038)$ & $(0.041)$ & $(0.029)$ & $(0.056)$ \\
\hline Observations & 3888 & 3876 & 4375 & 3863 \\
$R^{2}$ & 0.203 & 0.435 & 0.010 & 0.016 \\
Firm FE and Year Trend & Yes & Yes & Yes & Yes \\
Year FE & Yes & Yes & Yes & Yes \\
Region FE & Yes & Yes & Yes & Yes \\
Controls & Yes & Yes & Yes & Yes \\
Excluding Threshold Range & Yes & Yes & Yes & Yes \\
\hline
\end{tabular}

Note. Dependent variables are log other inputs, total inputs, ratio of raw materials to revenue, ratio of total inputs to revenue (in logs). Significance levels: $* * *(1 \%), * *(5 \%)$, and $*(10 \%)$. Robust standard errors (in parenthesis). Clustering at the industry level. Big means firm with revenue higher than the VAT eligibility threshold of 500000 Birr. Control variables include age of firms, type of ownership (private or public). The excluded threshold range includes all firms that are at least 58,000 Birr away (below and above) from the turnover threshold. 
Table A3. Effect of VAT policy on other inputs (in Logs)

\begin{tabular}{lcccc}
\hline & Wage Bill & Workers & Working Capital & Investment \\
\hline Post ${ }_{2002} \times$ Big & $0.138^{* *}$ & -0.046 & $0.222^{* * *}$ & 0.206 \\
AgeFirm & $(0.067)$ & $(0.079)$ & $(0.081)$ & $(0.315)$ \\
& 0.056 & 0.026 & -0.028 & -0.362 \\
Type of ownership & $(0.058)$ & $(0.048)$ & $(0.109)$ & $(0.223)$ \\
& $0.245^{* * *}$ & $0.202^{* * *}$ & 0.140 & -0.239 \\
Lag Log Sale & $(0.035)$ & $(0.050)$ & $(0.086)$ & $(0.220)$ \\
& $0.243^{* * *}$ & $0.177^{* * *}$ & $0.315^{* * *}$ & $0.190^{* *}$ \\
\hline Observations & $(0.016)$ & $(0.016)$ & $(0.034)$ & $(0.091)$ \\
$\mathrm{R}^{2}$ & 4383 & 4379 & 3974 & 2425 \\
Firm FE and Year Trend & 0.405 & 0.192 & 0.398 & 0.045 \\
Year FE & Yes & Yes & Yes & Yes \\
Region FE & Yes & Yes & Yes & Yes \\
Controls & Yes & Yes & Yes & Yes \\
Excluding Threshold Range & Yes & Yes & Yes & Yes \\
\hline
\end{tabular}

Note. Dependent variables are wage bill paid to workers, number of workers employed, working capital, and investment in fixed capital (in logs). Significance levels: $* * *(1 \%), * *(5 \%)$, and $*(10 \%)$. Robust standard errors (in parenthesis). Clustering at the industry level. Big means firm with revenue higher than the VAT eligibility threshold of 500000 Birr. Control variables include age of firms, type of ownership (private or public). The excluded threshold range includes all firms that are at least 58,000 Birr away (below and above) from the turnover threshold.

Table A4. Effect of VAT policy on exporters

\begin{tabular}{lcc}
\hline & Wage Bill & Investment \\
\hline Post2002 $\times$ Exporter & 0.139 & 0.460 \\
& $(0.069)$ & $(0.230)$ \\
AgeFirm & 0.055 & -0.471 \\
& $(0.044)$ & $(0.221)$ \\
Type of ownership & 0.264 & -0.193 \\
& $(0.040)$ & $(0.198)$ \\
Lag Log Sale & 0.261 & 0.260 \\
& $(0.017)$ & $(0.112)$ \\
Observations & 3292 & 2143 \\
R2 & 0.397 & 0.057 \\
\hline Firm FE and Year Trend & Yes & Yes \\
Year FE & Yes & Yes \\
Region FE & Yes & Yes \\
Controls & Yes & Yes \\
Excluding Threshold Range & Yes & Yes \\
\hline
\end{tabular}

Note. The regressions include only Big firms (firm with revenue higher than the VAT eligibility threshold of 500000 Birr). Dependent variables are log wage bills and log investment in fixed capital. *** indicate significance at the $1 \%$ level, **at the 5\% level, and * at the $10 \%$ level. Robust standard errors, in parenthesis, are clustered at the industry level. Exporter means the firm has some revenue exported. Control variables include age of firms, type of ownership (private or public). The excluded threshold range includes all firms that are at least 58,000 Birr away (below and above) from the turnover threshold.

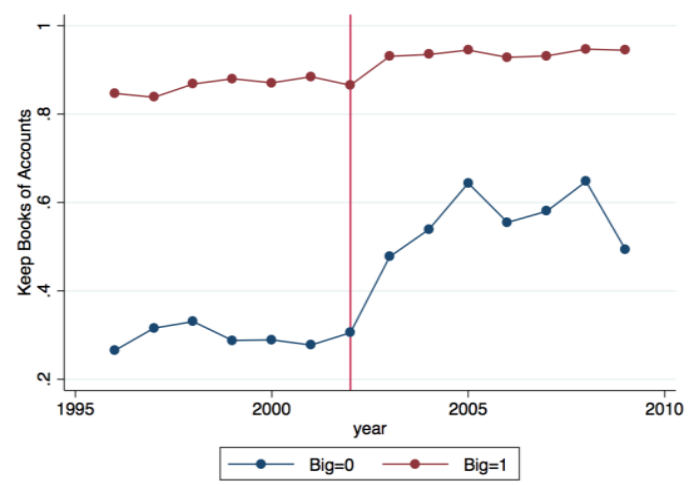

Figure A1. Whether firm keeps books of accounts over time 

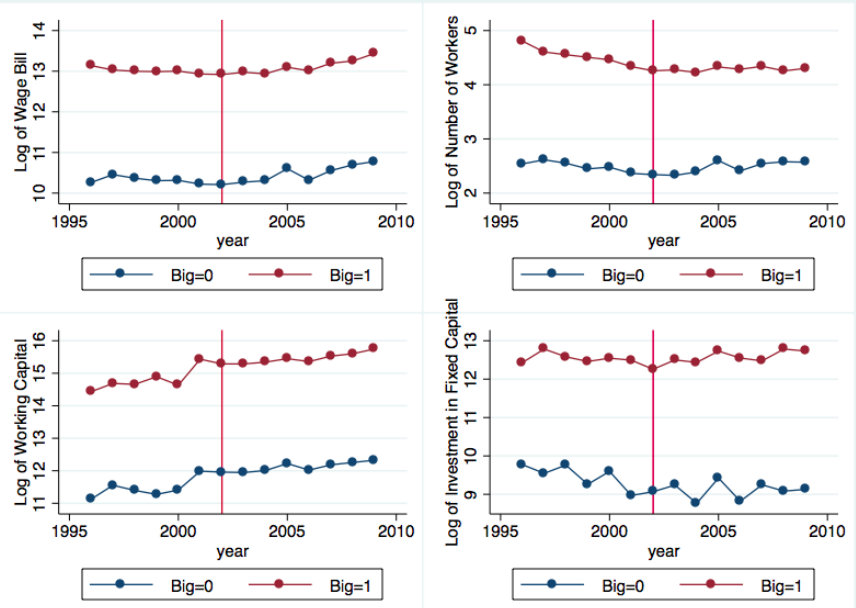

Figure A2. Effect of VAT policy on labor and capital

\section{Copyrights}

Copyright for this article is retained by the author(s), with first publication rights granted to the journal.

This is an open-access article distributed under the terms and conditions of the Creative Commons Attribution license (http://creativecommons.org/licenses/by/4.0/). 